\title{
The influence of corporate board on non-financial disclosure according to the main organizational theories
}

\author{
Bernardino Quattrociocchi*, Silvia Sergiacomi**, $^{* *}$ \\ Francesco Mercuri ${ }^{* * *}$
}

Ricevuto il 23/10/2019 - Accettato il 18/11/2019

\begin{abstract}
This study aims to define a theoretical framework of the main organisational theories identifying how the board composition influences both CSR activity and disclosure. Based on a selective literature review, the analysis highlights the implications of each organisational theory on non-financial information disclosure and board's role. Specifically, the research shows that the management's influence on non-financial information practice of an organisation is not emphasized by all organizational theories. In addition, based on the research results, non-financial information can should be considered as an organizational tool to legitimise the firm performance and manage the perception of enterprises stakeholders. The study could be further developed by applying quantitative research methods, such as a multiple case study approach, which is useful to explore the dissemination of a new phenomenon.
\end{abstract}

Key words: corporate social responsibility, disclosure of non-financial information, Corporate Governance, board of directors, corporate social responsibility disclosure.

Sommario. L'influenza del management sull'informativa non finanziaria secondo le principali teorie organizzative. Lo studio mira a definire un quadro teorico delle principali teorie organizzative, identificando come la composizione del board impatta sulla responsabilità sociale d'impresa. Mediante una review della letteratura, il lavoro si propone di evidenziare le implicazioni che ciascuna teoria orga-

\footnotetext{
* Full Professor Business Management Sapienza, University of Rome, bernardino.quattrociocchi@uniroma1.it

** Ph.D. student in Governance and Management for Business Innovation, University Niccolò Cusano, silvia.sergiacomi@unicusano.it

${ }^{* * *}$ Research Fellow Business Management Sapienza, University of Rome, francesco.mercuri@uniromal.it
}

Corporate Governance and Research \& Development Studies, supplemento al n. 1-2019 ISSN 2704-8462 
nizzativa prevede circa la divulgazione di informazioni non finanziarie e l'influenza del board. In particolare, la ricerca mostra che non tutte le teorie organizzative considerano l'influenza della direzione sulla realizzazione e divulgazione delle informazioni non finanziarie. Inoltre, secondo quanto emerso, la promozione di informazioni non finanziarie inerenti l'azienda è da considerarsi strumento utile nel legittimare le performance aziendali e influenzare la percezione e le aspettative degli stakeholder.

Infine, lo studio potrebbe essere ulteriormente sviluppato applicando metodi di ricerca quantitativa, come un "multiple case study approach", utile per esplorare la diffusione del fenomeno.

Parole chiave: responsabilità sociale delle imprese, promozione delle informazioni non finanziarie, organo di governo.

\section{Introduction}

According to Gray et al. (2010, p. 6),

«Theory is, at its simplest, a conception of the relationship between things. It refers to a mental state or framework and, as a result, determines, inter alia, how we look at things, how we perceive things, what things we see as being joined to other things and what we see as "good" and what we see as "bad". Specifically, regarding social accounting, it is necessary to have theories that help us to observe, organise, and explain a series of things, such as defining what is meant by social accounting, its effects, what problems the social accounting seeks to solve, and what makes a good or bad practice of social accounting» (Gray et al., 2010).

Within corporate social responsibility (CSR) accounting, a series of theories was produced concerning the motivation of companies to disclose information about their CSR activities and the explanation of why an organisation tends to disclose IC information (An et al., 2011; Dumay and Guthrie, 2017). In other words, theories combine different approaches and use the same terminology with different meanings (Garriga and Melè, 2004).

Many of these theories are interrelated and are part of an integrated framework based on the premise that corporate disclosure has a positive effect on corporate performance by, for example, reducing information asymmetry, discharging accountability, signalling legitimacy, and achieving excellence (An et al., 2011). In this paper, we analyse the main organisational theories that have implications for non-financial information disclosure and disclosure of diversity information.

Social accounting is an essential aspect of CSR; in fact, it is considered as 
a mechanism aimed at enhancing corporate accountability and transparency to stakeholders, addressing the social, environmental, and ethical values. Moreover, the establishment of the mechanisms for monitoring and controlling a company's activities falls within the responsibility of the board of directors, which, therefore, is responsible for the accountability and transparency of a company through information disclosure (Dias et al., 2017). Thus, based on the relation between the board decisions and the involvement in CSR practices and related disclosure, it may be interesting to analyse how the board composition influences the CSR activity and the CSR disclosure.

The remainder of the paper is organised as follows. The next section reviews the theoretical foundations of Corporate Governance and CSR, highlighting the board's capability to influence disclosure of non-financial information. The third section analyses the main organisational theories to identify their implications for non-financial information disclosure and board's role. Finally, the last section presents our discussion and conclusion.

\section{CSR and the board of directors}

According to Bear et al. (2010), Corporate Governance and corporate sustainability should not be considered independently of each other. Corporate Governance planning requires the implementation of sustainable goals, which provides structural measures that have repercussions on the company's establishment. Therefore, it is important to redefine the governance system that is responsible for defining and implementing corporate sustainability strategies (Van Marrewijk, 2003).

Specifically, the link between Corporate Governance and corporate sustainability is defined as a two-way relationship. It is important that corporate sustainability governance is part of the corporate leadership, so Corporate Governance needs to be reconfigured and corporate sustainability has to be integrated into a company's functions transversally involving all management processes (Naciti, 2019).

CSR can be defined as an activity of companies that look beyond profits and pay more attention to transparency, ethical values, relationships with employees, and respect for the law. In other words, CSR is the strategy with which a firm expresses its identity and the actions that allow applying this identity. Based on enlarged governance, CSR has effects on the internal organisation of the company and the external context with which it is active (Arora and Dharwadkar, 2011). Specifically, the internal dimension of the company includes the management of human resources, workers' rights, 
health and safety at work, and the management of natural resources and environmental effects. Among these aspects, the most important field for the application of social responsibility practices is the internal management of human resources. On the other side, the external dimension on which the CSR has effects is related to consumers, local communities, suppliers and customers, and environmental, social, and human rights issues.

Based on the CSR perspective, non-financial disclosure has become fundamental because it involves broader aspects than financial accounting for shareholders, such as the different dimensions related to the social, environmental, ethical, risk, and governance aspects, which may be of interest to all stakeholders (Manes-Rossi et al., 2018). According to Aldrugi and Abdo (2014), the importance of CSR disclosure is highlighted by different aspects; in fact, it produces many benefits for both the society in which the entity operates and the reporting entity. Moreover, comprehensive disclosure of the CSR activities and sustainability position of a firm represents its reporting quality (Abdo and Al-Drugi, 2012). Thus, the dissemination of the transparency culture allows recovering the effectiveness of economic and financial communication.

CSR reporting aims to respond to external pressures arising from different stakeholders; in fact, it is considered as a way of communication between an enterprise and its stakeholders, providing information about an enterprise's strategy, social policies, and CSR performance (Dumay, 2016; Dumay et al., 2015; Matuszak and Ròzanska, 2017). In other words, disclosing CSR information means providing information about the social and environmental aspects of the company's operations. Therefore, according to Carini et al. (2017), non-financial information could help managers, and other stakeholders, to make decisions more consciously.

In addition to the relationship with corporate sustainability, Corporate Governance allows defining how companies are organised by specifying the function, structure, and role of the board of directors. The board of directors of a firm is the body that determines policies for corporate management and makes decisions on major company issues (Naciti, 2019), so it ensures close alignment between the interests of shareholders and managers. In other words, the board is the main vehicle by which Corporate Governance takes place, so based on the direction of the firm's operations and decision-making, it is responsible for protecting the specific interests of stakeholders of a firm. Therefore, according to Terjesen et al. (2014), strong Corporate Governance can mitigate agency problems and encourage managers to operate properly.

Recently, the composition of corporate boards and board diversity has 
been a growing research field (Cucari et al., 2018; Huse et al., 2009; Nielsen and Huse, 2010; Seierstad et al., 2017; Solimene et al., 2017). Board diversity can be defined as variety in the composition of the board of directors, and it may affect the effectiveness of the corporate board in a different way because it is presented as both fiduciary and advisory (Hoang et al., 2016).

\section{The roles of the board according to the main organisational theories}

In the following sections, we analyse the main organisational theories in order to identify their implications on non-financial information disclosure and board's role. Therefore, we performed a selective literature review of the main organisational theories, selecting in particular those that reveal a specific focus on non-financial information practice and, also, the motivation that leads a firm to disclose CSR information (An et al., 2011; Dumay and Guthrie, 2017). Moreover, we identify the theories that highlight the significant roles of the board of directors in order to describe how it should be structured to deal efficiently with the relationships with the main organisational actors. In addition, in order to define a theoretical framework, for each theory we highlighted its implications on non-financial information disclosure and board's role.

\subsection{Agency theory}

An agency relationship is defined by Jensen and Meckling (1976) «as a contract under which one or more persons (the principal(s)) engage another person (the agent) to perform some service on their behalf which involves delegating some decision-making authority to the agent» (p. 308). The most commonly studied principal-agent relationships are between the shareholder and the management, the major and minor owners, and the creditor and shareholder (or management) of an organisation, categorised into three types of the agency problem (Fama and Jensen, 1983; Gilson and Gordon, 2003). Specifically, both the principal and the agent are utility maximisers, so they try to maximise their individual interests, and, consequently, their interests are not aligned; this can cause conflicts of interest, producing the agency problem, which can only be avoided if the parties fully share the same interests (Fama and Jensen, 1983; Jensen and Meckling, 1976).

According to Ness and Mirza (1991), in the agency theory field, man- 
agers tend to disclose information if it involves an increase of their benefits, which, in other words, occurs when the benefits deriving from disclosure are higher than the related costs. However, referring to the agency theory and CSR disclosure, non-financial disclosure reduces the information asymmetry between the principal and the agent, and also between shareholders and the management in the corporate context. As a result, it could eliminate agency problems and reduce opportunistic behaviour, offering to shareholders the opportunity to monitor the company (An et al., 2011).

Agency theory is among the most recognised in research on the contribution of boards (Huse, 2007). This approach provides the rationale for the board's critical function of monitoring management on behalf of the shareholders (Fama and Jensen, 1983); thus, the board needs the appropriate mix of experience and capabilities to evaluate management and assess business strategies and their impact on CSR (Bear et al., 2010).

According to agency theory, «board contribution to organizational performance occurs by reducing agency cost arising from noncompliance of executives with established goals and procedures, by articulating shareholders' objectives and focusing the attention of key executives on company performance, and through strategic decision making and control» (Huse, 2007, p. 123). Concerning board diversity, agency theory suggests that diversity of the corporate board leads to the increase of board independence and a consequent improvement of the ability of the board to monitor management, with a positive impact on the firm's financial performance (Galbreath, 2018).

\subsection{Shareholder theory}

Shareholder theory treats the shareholders as the only group to which the organisation must be socially responsible, because it assumes that the interests of management and shareholders are the same. According to Friedman (1970), a corporation is an artificial person, and so it may have artificial responsibilities because only people can have responsibilities, but "business" as a whole cannot be said to have responsibilities, even in this vague sense.

From the shareholder perspective, in a private-property system with a free enterprise, a corporate executive is an employee of the owners of the business who has direct responsibility to his or her employers to manage the business in line with their wishes. Thus, the corporate executive is an agent who serves the interests of his or her principal (Friedman, 1970) 
based on the deontological obligations deriving from the contract between managers and shareholders (Mansell, 2013). In other words, managers have a moral duty to maximise the value of the investment of their principals (shareholders).

Regarding non-financial disclosure, shareholders require companies to disclose information concerning their prospects for future performance and the sustainability of actual value-creation drivers. This involves effective communication about the risks that affect a firm's strategies and the actions aimed to reduce as much as possible the risk of failures and make the most of emerging opportunities (Antonelli et al., 2016). Therefore, based on stakeholder theory, an organisation pursues CSR practices in order to understand and satisfy its stakeholders.

\subsection{Stewardship theory}

According to Davis et al. (1997), «stewardship theory defines situations in which managers are not motivated by individual goals, but rather are stewards whose motives are aligned with the objectives of their principals» (p. 21). In order to achieve collective goals, the steward tends to put in place collectivist and pro-organisational behaviours, trying to achieve the objectives of the organisation (Davis et al., 1997; Di Carlo, 2017).

According to stewardship theory, the behaviour of the executive is aligned with the interests of the principals, and consequently, there is a strong relationship between the principal's satisfaction and the success of the organisation (Davis et al., 1997; Donaldson and Davis, 1989, 1991). In fact, in maximising the shareholders' wealth, the steward also maximises his or her utility functions (Davis et al., 1997; Di Carlo, 2017). Specifically, «the steward's opportunity set is constrained by the perception that the utility gained from pro-organizational behaviour is higher than the utility that can be gained through individualistic, self-serving behaviour» (Davis et al., 1997, p. 25).

According to stewardship theory, the main board tasks are service tasks and, specifically, collaborating strategy involvement, including mentorship. The role of boards is guiding management in achieving the missions and objectives of the enterprise (Huse, 2007). Therefore, like the agency theory, for stewardship theory the organisation is an instrument used by the shareholder to maximise the return of his or her investment (Di Carlo, 2017). Moreover, as suggested by the agency theory, the stewardship theory explains the practice of voluntary disclosure that inspires the corporate disclosure policy regarding sustainability at the corporate level because the 
proportion of financial and non-financial information can reduce the information problem.

\subsection{Resource dependence theory}

According to Pfeffer and Salancik (1978), resource dependence theory states that the organisation is an open system, and its behaviour is influenced by external factors. It is based on the assumptions that the resources in the environment are necessary for the survival of an organisation, but the procurement process of these resources is uncertain because they are rare, valuable, and inimitable.

The acquisition of external resources needed for the organisation causes a modification of the organisation's power relations with other organisations. In fact, it leads to a decrease of the organisation's dependence on others and/or to an increase of others' dependence on it.

Moreover, resource dependence theory is based on the concept of the power that is central because it allows to control vital resources. Organisational success is achieved when organisations maximise their power. In other words, much of the operation and structure of an organisation depend on the nature of the power relations between more organisations (Ulrich and Barney, 1984).

In recent years, numerous studies devoted to CSR adopting a vision based on resources have been conducted (Branco and Rodrigues, 2006). Specifically, «the resources dependence perspective can be extended to consider the role of social responsibility disclosure as a signal of improved social and environmental conduct and hence reputation in those fields because disclosure influences the external perception of reputation» (Branco and Rodrigues, 2006, p. 125).

Regarding board diversity, resource dependence theory identifies critical resources that the board's function can provide to companies, including legitimacy, advice, and counsel (Pfeffer and Salancik, 1978). According to this theory, thanks to these board resources, the company is able to understand and respond to its environment, which can help it better manage CSR issues. In this perspective, cooperation and connection are two benefits for companies (Huse, 2007). Thus, directors are also valuable resources for companies' management because they help companies manage environmental interdependencies thanks to their connections with stakeholders.

Regarding the disclosure of board diversity, resource dependence theo- 
ry suggests that it allows an organisation to develop its ability to obtain critical resources to cover stakeholders' claims. In this sense, board diversity can improve the disclosure of value-relevant information, enhancing strategic decisions in relation to external stakeholders (Bravo, 2018). In other words, according to resource dependence theory, diversity among directors is a fundamental resource for a firm because it allows the organisation to adopt relevant disclosure practices to stakeholders, addressing corporate social disclosure issues (Hoang et al., 2016).

In general terms, resource dependence theory recognises that the board contributions have a direct impact on a firm's CSR, such as enhancing the legitimacy and image of the firm, facilitating access to key resources, or linking the firm to important stakeholders.

\subsection{Stakeholder theory}

Stakeholder theory expects that managers must identify and apply processes aimed at exclusively meeting the groups that have an interest in the business of a company (Freeman, 1984). In fact, the main goal of this approach is to manage and integrate the relationships and interests of different kinds of stakeholders, such as shareholders, customers, employees, communities, and suppliers, in order to ensure the long-term success of the company (Freeman and McVea, 2001). Freeman (1984, p. 260) states that stakeholder theory enters in the CSR debate by suggesting that the managers of the corporations have a responsibility not simply to serve the general interests of society, but rather to serve the interests of the corporation's stakeholders. In conclusion, «stakeholder theory can be used to help define the social account, first of all by informing the process of stakeholder identification, and then breaking down the general stakeholder categories into their constituent» (Freeman, 1984, p. 253).

According to Guthrie et al. (2006), «stakeholder theory highlights organisational accountability beyond simple economic or financial performance. It suggests that organisations will elect to voluntarily disclose information about their intellectual, social, and environmental performance, over and above mandatory requirements, in order to meet real or perceived stakeholder expectations» (p. 256). Therefore, the stakeholder theory is a powerful means to explain, justify, and understand financial reporting and disclosure. In fact, management may use corporate disclosure as a tool for managing the information needs of most powerful stakeholders and manipulate them in order to obtain their support, which is necessary for 
their survival (Gray et al., 1996). In other words, this perspective suggests that Corporate Governance and CSR disclosure should aim to enhance stakeholder engagement and organisational legitimacy. CSR disclosure is considered as a strategic response to society's expectations (Gray et al., 1995), so the development of a corporate reputation through performance and disclosure represents a strategic approach to managing stakeholder relationships (Dias et al., 2017).

\subsection{Legitimacy theory}

The legitimacy theory claims that the state of legitimacy is essential for the survival of an organisation because it is continually seeking to ensure that its activities respect the limits and norms of the societies in which it operates (Cuganesan et al., 2007). Referring to the legitimacy theory, there is a "social contract" that regulates the relation between a company and its society, with which the society expresses multiple expectations about how an organisation should conduct its operations.

According to Suchman (1995), legitimacy is defined as a generalised perception that the actions of an entity are desirable and appropriate within a social system of values, norms, and beliefs. In particular, organisational legitimacy is not fixed but changes continuously, and thus organisations must necessarily adapt their activities to the requirements of legitimacy.

However, a legitimacy gap can threaten the legitimacy of an organisation, and it often arises when the perception of society regarding the way an organisation should act and the actions actually performed by the organisation diverge (An et al., 2011). In order to reduce the legitimacy gap, an organisation can adopt various strategies, such as informing its stakeholders on the actual change of its performance or changing the stakeholders' perceptions about its activities without changing its actual behaviour. Due to the disclosure of non-financial information, firms are able to legitimise their performance and manage the perception of their stakeholders (Cucari et al., 2018). Managers may have different perceptions of legitimacy, and so they may adopt different strategies to achieve the desired level of legitimacy. "Organizations should voluntarily report on information that is expected by society since the compliance of societal expectations could result in continued inflows of capital, labour and customers» (An et al., 2011, p. 577).

Therefore, the public disclosure of information would be an effective 
tool to apply these strategies. In this sense, «legitimacy theory suggests that reporting is used as a communication mechanism to inform and/or manipulate the perceptions of the firm's actions» (Tilt, 2009, p. 15). CSR disclosure is able to enhance the effect of CSR on corporate reputation because it represents a signal of improved social and environmental conduct (Branco and Rodrigues, 2006). Through the legitimisation strategy, organisations try to disclose their CSR activities in order to communicate their legitimisation actions.

\subsection{Signalling theory}

Signalling theory deals with finding possible solutions to problems related to information asymmetry in social contexts and, consequently, reducing information asymmetry between two parties (Spence, 2002). The classic signalling model occurs in a market setting between the seller and the buyer, where the seller usually has an information advantage over the buyer about the characteristics of its services and products. Generally, buyers do not have much information about specific goods, but they may have general perceptions in purchasing that they will do. Consequently, the seller of high-quality products has an incentive to signal the quality of his or her products to the buyer for legitimising the highest selling price (An et al., 2011).

Applying the classic model in a company context, the management of a company generally has more information than investors with regard to the specific functioning of the company. Therefore, information asymmetry is created, and it does not allow investors to fully understand the quality of the company and, consequently, they cannot compare the quality of the various companies. Therefore, the high-quality company has an incentive to signal its advantages to the market, emphasising its superior quality in order to attract more investors (An et al., 2011).

Regarding non-financial disclosure, corporate disclosure has a positive effect on corporate performance by signalling legitimacy. In general terms, «annual reports are a highly useful source of data, because managers of companies commonly signal what is important through the reporting mechanism» (Guthrie and Petty, 2000, p. 244).

According to signalling theory, companies that have a high quality should signal their advantages to the market. In this way, investors and other stakeholders are able to evaluate the value of the company and make decisions with greater awareness and more favourability to the company. At 
the same time, encouraging stakeholders, the signalling would allow a company to get more investment and reduce the costs of raising capital (An et al., 2011).

Concerning the relationship between board diversity and corporate reputation, the signalling theory expects that the board gender composition disclosure may represent a signal able to indicate that the firm is socially responsible, due to paying attention to women and minorities on a firm's board (Bear et al., 2010).

In conclusion, CSR disclosure is treated by signalling theory as a signal able to improve the organisation's corporate image, attract investors, and improve its relationships with stakeholders.

\section{Final remarks and further considerations}

In the last few years, disclosure of non-financial information has received growing attention because it could help managers, and other stakeholders, to make decisions more consciously (Carini et al., 2018). Thus, in addition to the transparency of financial activities disclosed in the annual report, stakeholders demand greater corporate accountability regarding performance, as well as social and environmental issues. In this perspective, the Corporate Governance is able to influence the transparency of corporate communications and disclosures, more specifically CSR disclosure (Adnan et al., 2018). So, board composition is an important determinant for CSR disclosure, since it is influenced by the choices, motives, and values of those who are involved in formulating and making decisions in the organisations (Hoang et al., 2016).

Regarding the disclosure of non-financial information, the organisational theories analysed in this study outline why organisations disclose corporate information based on the assumption that corporate disclosure has a positive effect on corporate performance by reducing information asymmetry, enhancing transparency, discharging accountability, signalling legitimacy, and achieving excellence (An et al., 2011). These evidences are represented in the following table which indicates how each theory defines the non-financial information and the board's role.

The analysis allowed us to verify that all theories provide a definition of non-financial information, but only some of these emphasize a direct link between non-financial information and board's role.

In detail, agency theory assigns a monitoring function to the board of directors that can allows the organization to reduce information asymmetry 
Tab. 1 - Non-financial information and board's role: some definitions based on the main organisational theories

\begin{tabular}{lll}
\hline Theories & \multicolumn{1}{c}{ Non-financial information } & \multicolumn{1}{c}{ Board's role } \\
\hline Agency theory & $\begin{array}{l}\text { Reduces information asymmetry be- } \\
\text { tween managers and shareholders }\end{array}$ & Monitoring function \\
Stewardship theory & $\begin{array}{l}\text { Reduces information problems } \\
\text { Shareholder theory }\end{array}$ & $\begin{array}{l}\text { Allows the organisation to enhance a } \\
\text { better transparency towards share- } \\
\text { holder }\end{array}$ \\
Stakeholder theory & $\begin{array}{l}\text { Enhances stakeholder engagement } \\
\text { and organisational legitimacy }\end{array}$ & n.a. \\
Resources dependence & $\begin{array}{l}\text { Improves social and environmental } \\
\text { performance, increasing the stake- } \\
\text { holder's perception }\end{array}$ & Manage environmental inter- \\
theory & $\begin{array}{l}\text { Allows the organisation to legitimise } \\
\text { its performance and manage the per- } \\
\text { ception of its stakeholders }\end{array}$ & \\
Legitimacy theory & $\begin{array}{l}\text { Socially responsible, due to paying } \\
\text { attention to women and minorities on } \\
\text { a firm's board }\end{array}$ & n.a. \\
Signalling theory &
\end{tabular}

Source: own elaboration.

between managers and shareholders. Shareholder theory states that based on the service tasks of the board, an organization is able to enhance transparency with its shareholder, which requires information related to the sustainability of actual value-creation drivers. At the same time, resources dependence theory recognizes to the board of directors a manage environmental interdependences role that could improve social and environmental performance, increasing the stakeholder's perception.

Moreover, the analysis showed that some organisational theories - such us shareholder theory, stakeholder theory, legitimacy theory and signalling theory - do not explicitly emphasize if and how the board of director can affect the non-financial information practices of an organisation.

In conclusion, we can observe that there is no universal theory on CSR disclosure suitable for all kinds of organisations; so, based on the main organisational theories, non-financial information disclosure should be considered as an organizational tool to legitimise the firm performance and manage the perception of enterprises stakeholders. Finally, from an empirical perspective, the research results suggest to practitioners to 
enhance the organizational commitment on non-financial information disclosure practice, also in consideration of the positive association between the level of CSR disclosure and the enterprise value. Therefore, in the medium-long term the implementation of CSR strategies could allow the organization to improve its business and achieve a competitive advantage.

\section{References}

Abdo H., Al-Drugi A. (2012). Do companies' characteristics play key roles in the level of their environmental disclosures?, Energy Research Journal, vol. 3, n. 1, pp. 1-11. DOI: 10.3844/erjsp.2012.1.11

Adnan S.M., Hay D., Staden C.J. (2018). The influence of culture and corporate governance on corporate social responsibility disclosure: A cross country analysis. Journal of Cleaner Production, vol. 198, pp. 820-832. DOI: 10.1016/j.jclepro.2018.07.057

Aldrugi A., Abdo H. (2014). Determining the motives or reasons that make companies disclose environmental information. Journal of Economics, Business and Management, vol. 2, n. 2, pp. 117-121. DOI: 10.7763/JOEBM.2014. V2.109

Allen W.T. (1992). Our schizophrenic conception of the business corporation. Cardozo Law Review, vol. 14, pp. 261-281. DOI: 10.9774/GLEAF. 97813155742885

An Y., Davey H., Eggleton I.R.C. (2011). Towards a comprehensive theoretical framework for voluntary IC disclosure. Journal of Intellectual Capital, vol. 12, n. 4, pp. 571-585. DOI: 10.1108/14691931111181733

Antonelli V., D’Alessio R., Cuomo F. (2016). Beyond stakeholders theory: financial reporting and voluntary disclosure in italian sme according to a unitary perspective. Economia Aziendale Online, vol. 7, n. 4, pp. 285-304. DOI: 10.13132/2038-5498/7.4.285-304

Arora P., Dharwadkar R. (2011). Corporate governance and corporate social responsibility (CSR): The moderating roles of attainment discrepancy and organization slack. Corporate Governance: An International Review, vol. 19, n. 2, pp. 136-152. DOI: 10.1111/j.1467 - 8683.2010.00843.x

Arthur E.E. (1987). The ethics of corporate governance. Journal of Business Ethics, vol. 6, n. 1, pp. 59-70. DOI: 10.1007/BF00382949

Bear S., Rahman N., Post C. (2010). The impact of board diversity and gender composition on corporate social responsibility and firm reputation. Journal of Business Ethics, vol. 97, n. 2, pp. 207-221. DOI: 10.1007/s10551-010-0505-2?

Branco M.C., Rodrigues L.L. (2006). Corporate social responsibility?and resource-based perspectives. Journal of Business Ethics, vol. 69, pp. 111-132. DOI: $10.1007 / \mathrm{s} 10551-006-9071-\mathrm{Z}$ 
Bravo F. (2018). Does board diversity matter in the disclosure process? An analysis of the association between diversity and the disclosure of information on risks. International Journal of Disclosure and Governance, vol. 15, n. 2, pp. 104-114. DOI: 10.1057/s41310-018-0040-4

Carini C., Rocca L., Veneziani M., Teodori C. (2017). The regulation of sustainability information: the contribution of directive 2014/95. Preprints, pp. 1-16.

Cucari N., Esposito De Falco S., Orlando B. (2018). Diversity of board of directors and environmental social governance: Evidence from Italian listed companies. Corporate Social Responsibility and Environmental Management, vol. 25, n. 3, pp. 250-266. DOI: 10.1002/csr. 1452

Cuganesan S., Ward L., Guthrie J. (2007). Legitimacy theory: a story of reporting social and environmental matters within the Australian food and beverage industry. Presented to the 5th Asian Pacific Interdisciplinary Research in Accounting (APIRA) Conference, pp. 8-10 July 2007, Auckland, New Zealand. Retrieved from https://ssrn.com/abstract $=1360518$

Davis J.H., Schoorman F.D., Donaldson L. (1997). Toward a stewardship theory of management. Academy of Management Review, vol. 22, n. 1, pp. 20-47. DOI: 10.5465/amr.1997.9707180258

Dias A., Lùcia Lima L., Russell C. (2017). Corporate governance effects on social responsibility disclosures. Australasian Accounting, Business and Finance Journal, vol. 11, n. 2, pp. 3-22. DOI: 10.14453/aabfj.v11i2.2

Di Carlo E. (2017). Interesse primario dell'azienda come principio-guida e bene comune. Torino: Giappichelli.

Donaldson L., Davis J.H. (1989). CEO governance and shareholder returns: Agency theory or stewardship theory. Paper presented at the annual meeting of the Academy of Management, Washington, DC.

Donaldson L., Davis J.H. (1991). Stewardship theory or agency theory: CEO governance and shareholder returns. Australian Journal of Management, vol. 16, n. 1, pp. 49-64. DOI: 10.1177/031289629101600103

Dumay J. (2016). A critical reflection on the future of intellectual capital: from reporting to disclosure. Journal of Intellectual Capital, vol. 17, n. 1, pp. 168184. DOI: $10.1108 / J I C-08-2015-0072$

Dumay J., Frost G., Beck C. (2015). Material legitimacy: Blending organisational and stakeholder concerns through non-financial information disclosures. Journal of Accounting and Organizational Change, vol. 11, n. 1, pp. 2-23. DOI: $10.1108 /$ JAOC-06-2013-0057

Dumay J., Guthrie J. (2017). Involuntary disclosure of intellectual capital: is it relevant? Journal of Intellectual Capital, vol. 18, n. 1, pp. 29-44. DOI: 10.1108/JIC-10-2016-0102

Eisenhardt K.M. (1989). An assessment and review. The Academy of Management Review, vol. 14, n. 1, pp. 57-74. DOI: 10.2307/258191

Fama E., Jensen M. (1983). Agency problems and residual claims. Journal of Law and Economics, vol. 26, n. 2, pp. 327-349. DOI: $10.1086 / 467038$ 
Freeman R.E. (1984). Strategic management: a stakeholder approach. Boston: Pitman.

Freeman R.E., McVea J. (2001). A stakeholder approach to strategic management. Darden Business School Working Paper, n. 01-02. DOI: $10.2139 /$ ssrn.263511

Friedman M. (1970). The social responsibility of business is to increase its profits. New York Times Magazine, vol. 33, pp. 122-126.

Galbreath G. (2018). Is board gender diversity linked to financial performance? The mediating mechanism of CSR. Business \& Society, vol. 57, n. 5, pp. 863889. DOI: $10.1177 / 0007650316647967$

Garriga E., Melé D. (2004). Corporate social responsibility theories: Mapping the territory. Journal of Business Ethics, vol. 53, n. 1-2, pp. 51-71. DOI: 10.1023/B:BUSI.0000039399.90587.34

Gilson R., Gordon J. (2003). Controlling controlling shareholders. University of Pennsylvania Law Review, vol. 152, n. 2, pp. 785-843. DOI: 10.2139/ssrn. 417181

Gray R., Kouhy R., Lavers S. (1995). Corporate social and environmental reporting: a review of the literature and a longitudinal study of UK disclosure. Accounting, Auditing \& Accountability Journal, vol. 8, n. 2, pp. 47-77. DOI: 10.1108/09513579510146996

Gray R.H., Owen D.L., Adams C. (1996). Accounting and accountability: Changes and challenges in corporate social and environmental reporting. London: Prentice Hall.

Gray R., Owen D., Adams C. (2010). Some theories for social accounting?: A review essay and a tentative pedagogic categorisation of theorisations around social accounting. In: Freedman M., Jaggi B. (Eds.), Sustainability, environmental performance and disclosure: Advances in environmental accounting and management, Bingley, UK: Emerald Group Publishing.

Guthrie J., Petty R. (2000). Intellectual capital: Australian annual reporting practices. Journal of Intellectual Capital, vol. 1, n. 3, pp. 241-254. DOI: 10.1108/ 14691930010350800

Guthrie J., Petty R., Ricceri F. (2006). The voluntary reporting of intellectual capital: comparing evidence from Hong Kong and Australia. Journal of Intellectual Capital, vol. 7, n. 2, pp. 254-271. DOI: 10.1108/ 146919306106 61890

Hoang T.C., Abeysekera I., Ma S. (2016). Board diversity and corporate social disclosure: evidence from Vietnam. Journal of Business Ethics, vol. 151, n. 3, pp. 833-852. DOI: 10.1007/s10551-016-3260-1

Huse M. (2007), Boards, governance and value creation: the human side of corporate governance. Cambridge University Press.

Huse M., Nielsen S., Hagen I.M. (2009). Boards of directors, codetermination and women directors: Societal and business case CSR illustrations from Norway. Journal of Business Ethics, vol. 89, n. 4, pp. 581-597. 
Jensen M.C., Meckling W.H. (1976). Theory of the firm: managerial behavior, agency costs and ownership structure. Journal of Financial Economics, vol. 3, n. 4, pp. 305-360. DOI: 10.1016/0304-405X(76)90026-X

Johnson J.L., Daily C.M., Ellstrand, A.E. (1996). Boards of directors: a review and research agenda. Journal of Management, vol. 22, n. 3, pp. 409-438. DOI: 10.1177/014920639602200303

Manes-Rossi F., Tiron-Tudor A., Niccolò G., Zanellato G. (2018). Ensuring more sustainable reporting in Europe using non-financial disclosure de facto and de jure evidence. Sustainability, vol. 10, n. 1162, pp. 1-20. DOI: 10.3390/ su10041162

Mansell S. (2013). Shareholder theory and Kant's "duty of beneficence". Journal of Business Ethics, vol. 117, n. 3, pp. 583-599. DOI: 10.1007/s10551-0121542-9

Matuszak L., Ròzanska E. (2017). CSR disclosure in Polish-listed companies in the light of Directive 2014/95/EU requirements: empirical evidence. Sustainability, vol. 3, n. 2304, pp. 1-18. DOI: 10.3390/su9122304

Naciti V. (2019). Corporate governance and board of directors: the effect of a board composition on firm sustainability performance. Journal of Cleaner Production, pp. 1-18. DOI: 10.1016/j.jclepro.2019.117727

Ness K.E., Mirza A.M. (1991). Corporate social disclosure: a note on a test of agency theory. British Accounting Review, vol. 23, n. 3, pp. 211-217. DOI: 10.1016/0890-8389(91)90081-C

Nielsen S., Huse M. (2010). Women directors' contribution to board decision making and strategic involvement: The role of equality perception. European Management Review, vol. 7, n. 1, pp. 16-29. DOI: 10.1057/emr.2009.27

Pfeffer J., Salancik G.R. (1978). The external control of organizations: A resource dependence perspective. New York: Harper \& Row.

Phillips M.J. (1993). Reappraising the real entity theory of the corporation. Florida State University Law Review, vol. 21, n. 4, pp. 1061-1124. https://ir.law.fsu. edu/lr/vol21/iss $4 / 1$

Seierstad C., Warner-Søderholm G., Torchia M., Huse M. (2017). Increasing the number of women on boards: The role of actors and processes. Journal of Business Ethics, vol. 141, n. 2, pp. 289-231. DOI: 10.1007/s10551-0152715-0

Solimene S., Coluccia D., Fontana S. (2017). Gender diversity on corporate boards: an empirical investigation of Italian listed companies. Palgrave Communications, vol. 3, n. 16109, pp. 1-7. DOI: 10.1057/palcomms.2016.109

Spence M. (2002). Signaling in retrospect and the informational structure of markets. American Economic Review, vol. 92, n. 3, pp. 434-459. DOI: 10.1257/ 00028280260136200

Suchman M.C. (1995). Managing legitimacy: strategic and institutional approaches. Academy of Management Review, vol. 20, n. 3, pp. 571-610. DOI: $10.2307 / 258788$ 
Terjesen S., Aguilera R., Lorenz R. (2014). Legislating a woman's seat on the board: Institutional factors driving gender quotas for boards of directors. Journal of Business Ethics, vol. 50, n. 2, pp. 233-251. DOI: 10.1007/s10551-0142083-1

Tilt C.A. (2009). Corporate responsibility, accounting and accountants. In: Idowu S., Leal Filho W. (Eds.), Professionals 'perspectives of corporate social responsibility. Berlin Heidelberg: Springer. DOI: 10.1007/978-3-642-02630-0_2

Ulrich D., Barney J.B. (1984). Perspectives in organizations: Resource dependence, efficiency, and population. Academy of Management Review, vol. 9, n. 3, pp. 471-481. DOI: $10.2307 / 258287$

Van Marrewijk M. (2003). Concept and definitions of CSR and corporate sustainability: between agency and communion. Journal of Business Ethic, vol. 44, n. 2-3, pp. 95-105. DOI: 10.1007/978-94-007-4126-3_32 